Ege Tıp Dergisi / Ege Journal of Medicine 2021; 60 (1): 6-12

\title{
Ratlarda oluşturulan pneumoperitoneum modelinde iskemi reperfüzyon hasarının over dokusu üzerine etkileri
}

\author{
Effects of ischemia reperfusion injury on ovarian tissue in the pneumoperitoneum \\ model created in rats \\ İzzet Musayeva ${ }^{1}$ (D) \\ Çağdaş Şahin ${ }^{1}$ (D) \\ Sabahattin Anıl Arı ${ }^{2}$ (D) \\ Dilek Taşkıran ${ }^{4}$ (D) \\ Fatih Oltulu ${ }^{3}$ \\ Teksin Çırpan $^{1}$ (D) \\ ${ }^{1}$ Ege Üniversitesi Tıp Fakültesi Kadın Hastalıkları ve Doğum Anabilim Dalı, İzmir, Türkiye \\ ${ }^{2}$ Menemen Devlet Hastanesi Kadın Hastalıkları ve Doğum Kliniği, İzmir, Türkiye \\ ${ }^{3}$ Ege Üniversitesi Tıp Fakültesi Histoloji ve Embriyoloji Anabilim Dalı, İzmir, Türkiye \\ ${ }^{4}$ Ege Üniversitesi Tıp Fakültesi Fizyoloji Anabilim Dalı, İzmir, Türkiye
}

\section{ÖZ}

Amaç: Çalışmanın amacı pneumoperitoneumun over dokusu üzerinde oluşturduğu olası iskemi reperfüzyon hasarının gösterilmesi ve D vitamininin bu hasar üzerindeki etkilerinin araştırılmasıdır.

Gereç ve Yöntem: Çalışmamızda her biri 7 denekten oluşan 3 grup şeklinde Sprague Dawley cinsi dişi sıçanlar kullanılmıştır. Pneumoperitoneum sağlandıktan 60 dakika sonra desuflasyon gerçekleştirilmiş, ve 30 dakika boyunca intraabdominal basınç normalize edilmiştir. Reperfüzyon periyodunu takiben overler çıkarılmış ve iskemi reperfüzyon hasarı değerlendirilmiştir. Histolojik olarak, overlerde folliküler dejenerasyon, vasküler konjesyon, inflamasyon, hemoraji, ödem ve DNA tamir mekanizmalarını değerlendirmek için PCNA (Proliferating cell nuclear antigen) düzeyine, biyokimyasal olarak da plazma AMH (Anti müllerian hormon) ve overde MDA (Malondialdehid), TAC (Total antioksidan kapasite) ve SOD (Süperoksid dismutaz) düzeyine bakılmıştır.

Bulgular: Histolojik olarak gruplar arasında farklılıklar saptanmış ve ayrıca PCNA değerleri iskemi grubunda sham ve $D$ vitamini grubuna göre anlamlı düzeyde yüksek bulunmuştur $(p<0.005)$. Plazma AMH sonuçları açısından Grup 2'de ölçülen AMH düzeylerinin Grup 1'e göre anlamlı derecede düşük olduğu ( $p=0.035$ ), MDA düzeylerinin de Grup 2' de Grup 1'e oranla anlamlı derecede yüksek olduğu saptanmıştır $(p=0.006)$.

Sonuç: Pneumoperitoneum over üzerinde ciddi derecede iskemi reperfüzyon hasarı oluşturmaktadır. Bu hasar D vitamini kullanımı ile azaltılabilir. D vitamini olumlu etkisi sayesinde ileri düzey çalışmalarla desteklenmek koşuluyla, sadece laporoskopik pneumoperitoneum modelinde değil, overin direkt ya da indirekt olarak oksidatif strese maruz kaldığı radyoterapi veya kemoterapi gibi uygulamalar öncesinde de proflaktik olarak kullanılabilir.

Anahtar Sözcükler: İskemi, reperfüzyon, proliferating cell nuclear antigen, D vitamini, anti müllerian hormon, malondialdehid.

\section{ABSTRACT}

Aim: The aims of present study were revealing possible ischemia-reperfusion damage caused by pneumoperitoneum on ovarian tissue and investigating effects of vitamin $D$ on this ovarian damage.

Materials and Methods: Twenty-one adult female Sprague Dawley rats were used in this study and these rats were divided into three groups, each contained seven subjects: Sham Group, IschemiaReperfusion and Ischemia-Reperfusion +Vitamin D Group.

\footnotetext{
Sorumlu yazar: Sabahattin Anıl Arı

Menemen Devlet Hastanesi Kadın Hastalıkları ve Doğum

Kliniği, İzmir, Türkiye

E-posta: s.anil.ari.md@gmail.com

Başvuru tarihi: 15.08.2020 Kabul tarihi: 13.10.2020
} 
In Ischemia-Reperfusion Group, desufflation was performed 60 minutes after pneumoperitoneum induction and intraabdominal pressure was normalized for 30 minutes. In the Ischemia-Reperfusion + Vitamin $D$ group, pneumoperitoneum induction was performed after $500 \mathrm{mg} / \mathrm{kg}$ of vitamin $D$ administration. After the reperfusion period, the ovaries were collected, and ischemia reperfusion damage was evaluated. Histochemical staining was performed to evaluate the follicular degeneration, vascular congestion, inflammation, hemorrhage and edema parameters in the ovaries. In addition, immunohistochemical PCNA (Proliferating cell nuclear antigen) staining was performed to evaluate DNA repair mechanisms. In biochemical analyzes, AMH (Anti-Mullerian hormone), MDA (Malondialdehyde), TAC (Total antioxidant capacity) and SOD (Superoxide dismutase) levels were examined in the ovaries.

Results: In histological evaluation, significant differences were found between the groups and also the PCNA values were significantly higher in the Ischemia-Reperfusion Group compared to the Sham and Ischemia-Reperfusion +Vitamin $D$ Groups $(p<0.005)$. Biochemical evaluation revealed that $A M H$ levels measured in Group 2 were significantly lower than Group $1(p=0.035)$, and MDA levels were significantly higher in Group 2 compared to Group 1 ( $p=0.006)$.

Conclusion: Results of present study showed that pneumoperitoneum causes severe ischemia reperfusion injury on the ovary. This damage can be reduced with the use of vitamin $D$. The findings point that vitamin $D$ can be used prophylactically not only in the laparoscopic pneumoperitoneum model, but also before radiotherapy or chemotherapy applications which ovary is directly or indirectly exposed to oxidative stress.

Keywords: Ischemia, reperfusion, proliferating cell nuclear antigen, vitamin $D$, anti-Mullerian hormone, malondialdehyde.

\section{GíRiş}

Günümüzde iskemi-reperfüzyon hasarı; miyokart enfarktüsü, serebrovasküler enfarktüs, organ transplantasyonları, kardiyopulmoner resüsitasyon, trombolitik tedavi ve hemorojik şok gibi birçok durumda hastalar için yüksek morbidite ve mortalite nedenidir. İskemi, dokuya oksijen ve diğer hayati maddelerin intiyacından daha az miktarda sağlanması olarak tanımlanabilir (1). Ayrıca, iskemi sürecinde ortaya çıkan metabolitlerin dokulardan uzaklaştırıması da aksar. Bu durumda aktive olan serbest oksijen radikalleri (SOR) lipit peroksidasyonuna ve dolayısıyla hücre zarı hasarına sebep olur (2). Toksik oksijen türevlerinin önemli ölçüde iskemik alanda toplanan polimorf nüveli lökositler ( $P N L)$ tarafından üretildiği düşünülmektedir. Reperfüzyon hasarı ise iskemi sonrası dokunun tekrar kanlanmasıyla oluşur (2).

Organizmanın yaşamını sürdürebilmesi için oksidan/anti-oksidan dengesinin sağlanması çok önemlidir. SOR'nin oluşumunu ve meydana getirdikleri hasarları önlemek ve detoksifikasyonu sağlamak üzere organizmayı koruyan sistem "antioksidan savunma sistemi" olarak isimlendirilir. Günümüze kadar antioksidan özelliği öne sürülmüş pek çok madde, çeşitli iskemi/Reperfüzyon (i/R) modellerinde test edilerek değerlendirilmiştir $(2,3)$. Uzun zamandır raşitizm (rikets) ile anılan $D$ vitamininin antiproliferatif, pro- diferansiyatif, proapoptotik ve immünomodülatör fonksiyonlar gibi kemik dokusu dışı etkilerinin anlaşılması, bu hormonun farklı yönleri ile tekrar incelenmesine neden olmuştur. $D$ vitamininin hedef dokulardaki klasik olmayan etkileri; immün fonksiyonların, diferansiyasyonun ve hormon sekresyonlarının regülasyonu ile hücresel proliferasyondur. Yapılan çalışmada Vitamin D reseptörü olmayan dişi farelerde uterin hipoplazi ile ovarian follikülogeneziste bozulma ve fertilitenin $\% 75$ oranında azaldığı gösterildiğinden, D vitamininin fertilite üzerine olan etkisinin dolaylı olmaktan çok doğrudan olduğunu düşündürmektedir (4). Yine, hayvan çalışmalarında $D$ vitamini eksikliğinin erkek sıçanlarda azospermi, hipomobilite, testiküler morfolojide bozulma yaparak fertilitede azalmaya neden olduğu gösterilmiştir (4).

Anti-Müllerian hormon (AMH), aynı zamanda Müllerian inhibiting substance (MIS) olarak da bilinir. Aktivinler ve inhibinler gibi TGF- $\beta$ (Transforming growth faktör- $\beta$ ) ailesine ait olan homodimerik glikoprotein bir hormondur. AntiMüllerian hormon sentezi primer foliküllerde başlar, gittikçe artar ve pre-antral ve antral folliküllerde pik yapar. Anti-Müllerian hormon düzeyleri günümüzde ovaryan rezervin değerlendirilmesi için menstürasyon gününden bağımsız olarak sıklıkla kullanılmaktadır. Over 
rezervinin iskemi reperfüzyon hasasından dolayı azaldığı ve bunun da $\mathrm{AMH}$ düzeylerine etki ettiği düşünülmektedir.

\section{GEREÇ VE YÖNTEM}

Gerçekleştirilen randomize kontrollü deneysel çalışma, Ege Üniversitesi Tıp Fakültesi Etik Kurulu'nun 26/07/2016 tarihli onayı ve Ege Üniversitesi Bilimsel Araştırma Projeleri (BAP) birimi 2016-TIP-029 protokol numaralı projesi kapsamında yapılmıştır. Çalışmamızda 24 aylık, gebe olmayan, 200-250 gr ağırlığında Sprague Dawley cinsi dişi sıçanlar kullanılmıştır. Hayvanlar $22 \pm^{0} \mathrm{C}$ ısıda, 12 saat karanlık, 12 saat aydınlık olan ve \%50-60 oranında nemlendirilen bir ortamda tutulmuştur. Deney gününe kadar sıçanların beslenmesinde standart pellet yem ve içme suyu kullanılmıştır.

Çalışma için her biri yedi sıçandan oluşan üç grup oluşturulmuştur.

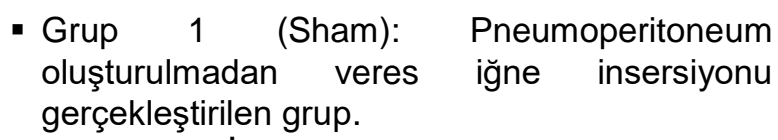

- Grup 2 (İskemi/Reperfüzyon): 60 dakika pneumoperitoneum ve 30 dakika reperfüzyon uygulanan grup.

- Grup 3 (D vitamini): İşlemden 30 dakika öncesinde oral $500 \mathrm{lU} / \mathrm{kg} \quad 1,25$ D vitamini verilmiş, sonrasında 60 dakika pneumoperitoneum ve 30 dakika reperfüzyon uygulanan grup.

Deney öncesinde anestezi Ketamin (Ketalar flakon $50 \mathrm{mg} / \mathrm{ml}$, Eczacıbaşı İlaç ve Ticaret A.Ş. İstanbul) $50 \mathrm{mg} / \mathrm{kg}$ intraperitoneal uygulanmıştır. Pneumoperitoneum öncesi sıçanlar standart cerrahi masaya sabitlenmiş, abdominal cilt temizliğini takiben $\% 10$ povidone iodin uygulamasıyla antisepsi yapılmıştır. 18G Abbocath kateter ksifoidal bölgeden abdominal kaviteye yerleştirilerek insufflator tüpe bağlanmış, CO2 insufflator cihazından $12 \mathrm{mmHg}$ hızıyla CO2 insuflasyonu sağlanmıştır. Pneumoperitoneum sağlandıktan $60 \mathrm{dk}$. sonra desufflasyon gerçekleştirilmiş ve $30 \mathrm{dk}$. boyunca intra abdominal basınç normalize edilmiştir.

Tüm gruplar için veres iğnesinin yerleştirilmesinden 90 dakika sonra orta hat abdominal insizyon uygulanarak overler alınmış, sağ overler histopatolojik inceleme, sol overler de biyokimyasal incelemeler için uygun solüsyonlara konulmuştur.

Histopatolojik değerlendirme için over doku örnekleri \%10 formalin solüsyonunda fiksasyon sonrası rutin histolojik takip yapıldıktan sonra parafine gömülmüş, sonrasında $4 \mu \mathrm{m}$ kalınlığında doku kesitleri hazırlanarak genel morfolojik bakı için hematoksilen-eozin ve immünohistokimyasal incelemeler içinde PCNA ile boyanmıştır. Kesitler mikroskopta (Olympus Bx5 Olympus Corp., Tokyo, Japan) incelenmiş ve dijital kamerayla (Olympus C-5050 Olympus Corp., Tokyo, Japan) görüntü alınmıştır. Histolojik veriler 0 ile 3 arasında skorlanmıştır. Skorlama sistemi; 0: patolojik bulgu saptanmadı, 1: patolojik bulgular $<\% 33,2$ : patolojik bulgular \%33-66 arasında, 3: patolojik bulgu boyutu>\%66 şeklinde standardize edilmiştir.

Biyokimyasal değerlendirme için çıkarılan over dokuları $-70{ }^{\circ} \mathrm{C}$ 'de saklanmıştır. Daha sonrasında $\mathrm{I} / \mathrm{R}$ hasarı boyutunun biyokimyasal olarak değerlendirilmesi için, overler $150 \mathrm{Mm}$ potasyum klorürde homojenize edilmiş ve 5000 rpm devirde 10 dakika santrifüj sonrası elde edilen materyalde malondialdehid (MDA), Superoksitdismutaz (SOD) ve total antioksidan kapasite (TAC) düzeyleri çalışılmıştır. Sıçanlara deney sonunda uygulanan ötenazi sırasında intrakardiyak yöntemle elde edilen kan örnekleri düz tüplere alınmış, tüpler $3000 \mathrm{rpm}$ hızında 10 dakika santrifüj edilerek serumları eppendorf tüplerine konarak ayrılmıştır. Örnekler $\mathrm{AMH}$ düzeyleri çalışılıncaya kadar $-70^{\circ} \mathrm{C}$ 'de saklanmıştır.

\section{BULGULAR}

Grup 1'den (Sham Grubu) elde edilen over materyallerinin incelenmesinde, overler ince fibröz bağ dokudan oluşan bir kapsül ile çevrelenmiş, üst kısmında germinal epitelin kübik şekilli hücrelerden oluştuğu görülmüştür. Ayrıca bazal membran düzgün ve düzenli olarak gözlenmiş, kapsülden parankima içine uzanan ince bağ dokusu bantları düzgün olarak izlenmiştir. Kortekste ovaryum dokusu içerisinde primordiyal folliküller, çeşitli çaplarda primer, sekonder ve tersiyer folliküller yer yer izlenmiştir. Folliküllerde bulunan oosit ve ona ait zona pellusida düzenli ve normal görülmüştür. Folliküllerin etrafında bulunan granüloza hücreleri poligonal, eozinofilik sitoplazmalı olup çekirdekleri kromatinden zengin ve yuvarlak olarak görülmüştür. Stroma içinde folliküller arasında yerleşmiş, interstisyel hücreler ve normal yapıda vasküler yapılar gözlenmiştir (Şekil-1A).

Grup 2'deki sıçanlardan alınan over örnekleri ışık mikroskobunda incelendiğinde, Grup 1'e oranla özellikle folliküllerin çevresinde yoğun olmak üzere korteks ve medullada yoğun polimorf nüveli lökositlerin (PNL) infiltrasyonu gözlenmiştir. 

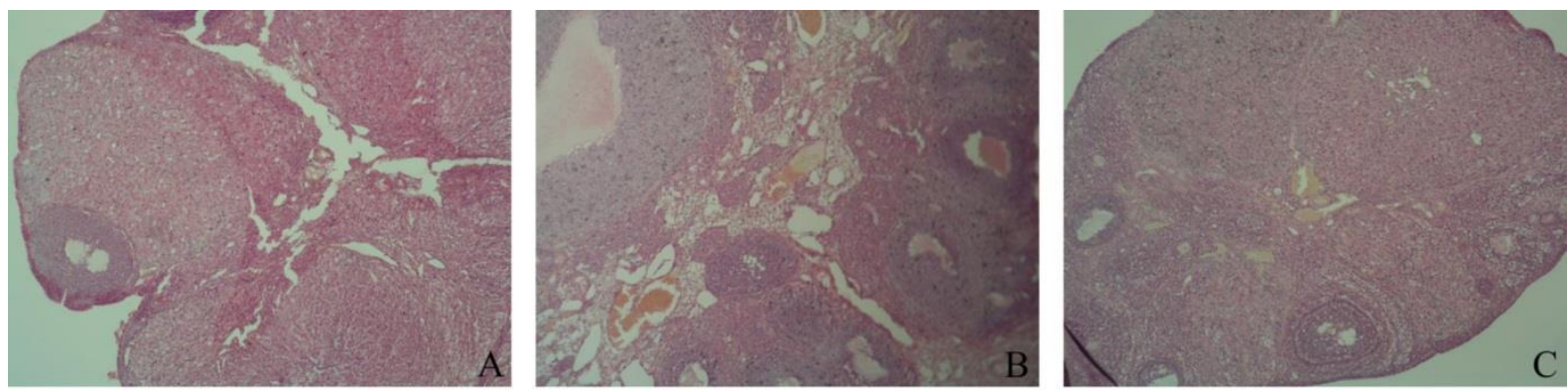

Şekil-1A. Sham grubu over Hematoksilen Eozin boyama (X40). (1B). İskemi reperfüzyon grubu over Hematoksilen-Eozin boyama (X40). (1C). D vitamini grubu over Hematoksilen-Eozin boyama (X40).
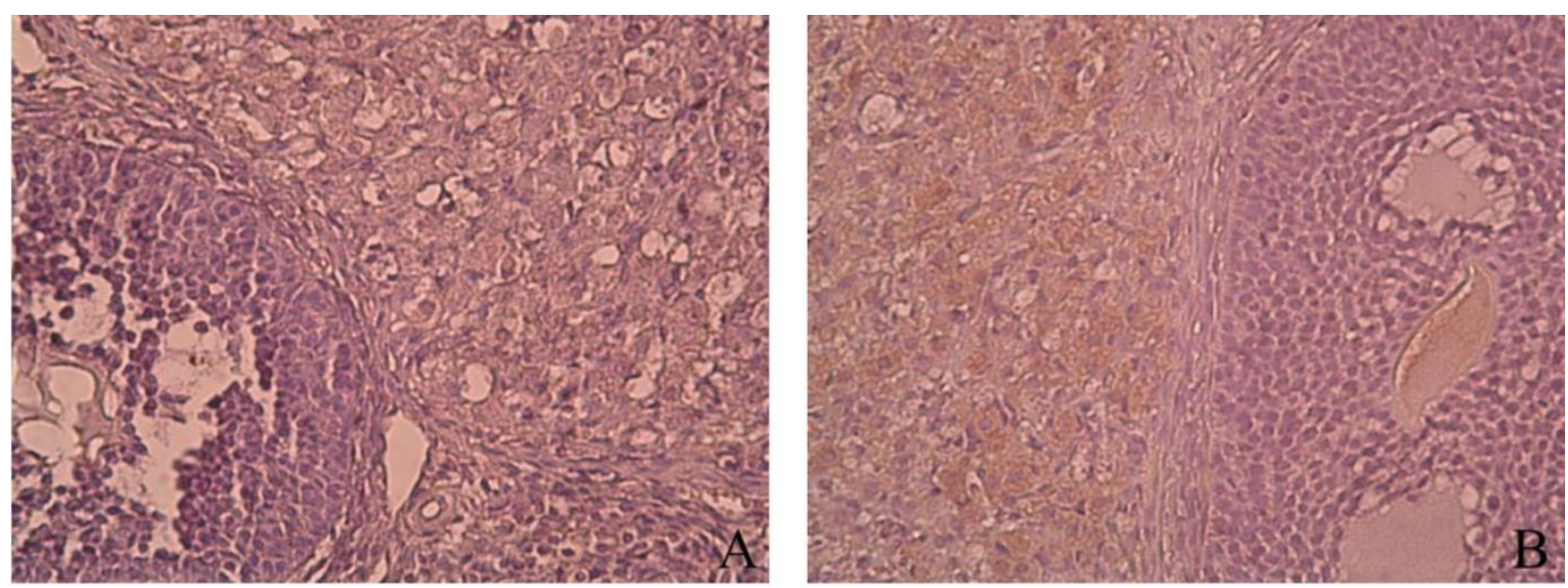

Şekil-2A. Sham grubu PCNA immünohistokimya boyaması (X40). (2B). I/R grubu PCNA immünohistokimya boyaması (X40).

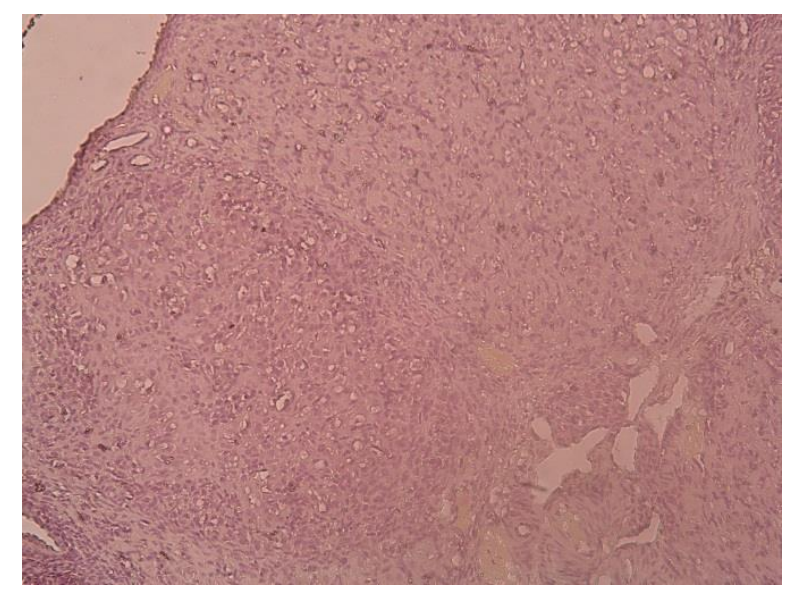

Şekil-3. D vitamin grubu PCNA immünohistokimya boyaması (X20).

Konjesyon ve hemorojik alanların hem korteks hem de medullada daha yoğun olduğu, corpus luteum alanlarında diğer tüm gruplara oranla küçülme ve folliküllerde dejenerasyon olduğu gözlemlenmiştir (Şekil-1B).
Grup 3'teki sıçanlardan alınan overlerin incelenmesinde ise folliküllerde ve interstisyel alanlarda Grup 2'ye oranla daha az hasar dikkati çekmiştir. İnterstisyel alanda ödem, diffüz hemoroji, inflamatuar hücreler ve vasküler dilatasyon görülse de bunların iskemireperfüzyon grubuna göre daha az yoğunlukta olduğu görülmüştür (Şekil-1C). Grup 2'ye ait over kesitleri sham grubu ile kıyaslandığında yüksek boyutta folliküler dejenerasyon ve ödem izlenmiştir ve bu fark istatistiki olarak anlamlıdır $(p<0.0001)$.

Nükleotid eksizyon tamiri mekanizmasının evrelerinden olan boşluk doldurulması ve ligasyon fazında rol oynayan, DNA oksidatif hasarının göstergesi olarak PCNA ekspresyonu, Grup 1'de \%35 (Şekil-2A), Grup 2'de \%61 (Şekil2B), grup 3'te \%44 olarak saptanmıştır (Şekil-3). PCNA değerleri I/R grubunda sham ve $D$ vitamin grubuna göre anlamlı düzeyde yüksek bulunmuştur $(p<0.005)$. D vitamini uygulanan gruptaki oksidatif stres hasar göstergesi olarak değerlendirilen PCNA değerlerinin iskemi grubu 
ile kıyaslandığında anlamlı düzeyde düşük bulunması $D$ vitamininin oksidatif hasarda koruyucu etkisinin olabileceğini göstermektedir (Şekil-4).

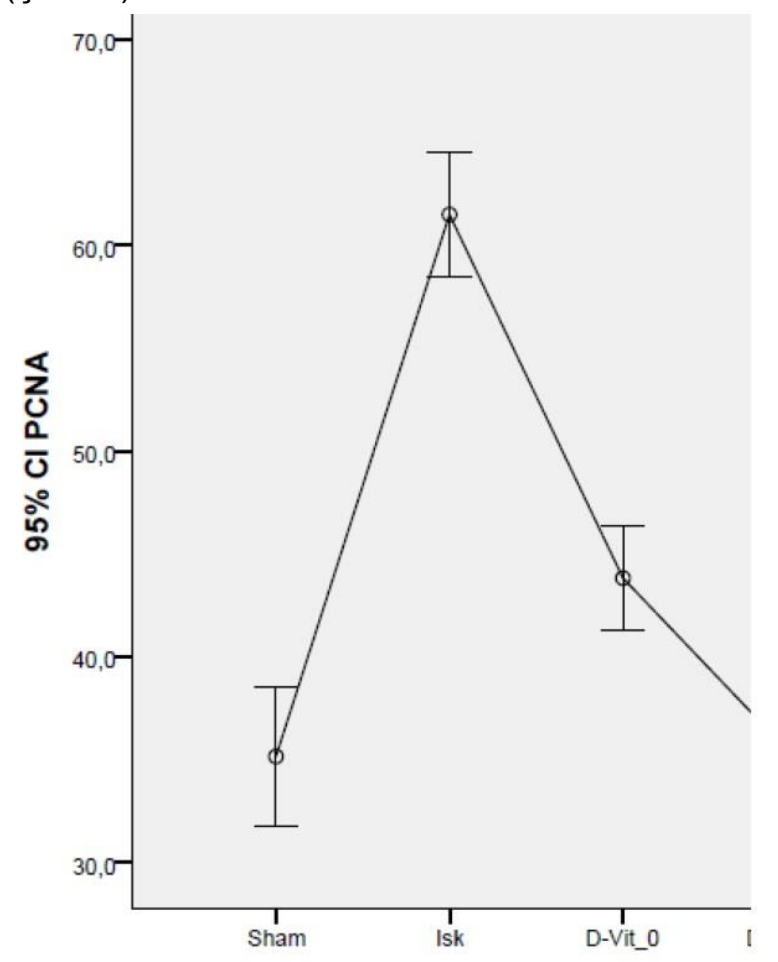

Şekil-4. PCNA aktivitesinin gruplar arası dağılımı.

Elde edilen over dokularından ölçülen MDA değerleri ortalama olarak, Grup 1 için 152.6 ( \pm 11.03$)$ nM; Grup 2 için $332.54( \pm 44.51) n M$; Grup 3 için 181.78 ( \pm 29.29$)$ nM bulunmuştur. Over dokularında ölçülen lipit peroksidasyonu belirteci MDA düzeyleri değerlendirildiğinde Grup 2 MDA düzeyinin Grup 1'e göre anlamlı yüksek olduğu saptanmıştır $(p=0.006)$. $D$ vitamini verilen Grup 3'te ölçülen MDA düzeylerinin Grup 2 ile kıyaslandığında ise anlamlı düzeyde azaldığı görülmüştür $(p=0.033)$. Bu sonuçlar İ/R modelinin overlerde anlamlı düzeyde oksidatif strese ve doku hasarına yol açtığını; İ/R modeli öncesi D vitamini verilmesinin gelişebilecek hasarı azaltabileceğini göstermektedir (Tablo-1).
Üç grup için sırasıyla ölçülen TAK değerleri ise sırasıyla, $210.37 \quad( \pm 15.25) ; 147.50 \quad( \pm 9.48)$; $231.17( \pm 7) \mu$ M'dir. Sonuçlar değerlendirildiğinde Grup 2 TAK düzeyinin Grup 1'e oranla anlamlı derecede düşük olduğu gözlenmiştir $(p=0.012)$. D vitamini verilen Grup 3'te elde edilen TAK düzeylerinin, Grup 2 ile kıyaslandığında ise anlamlı düzeyde yüksek olduğu görülmüştür $(p=0.0001)$. Bu sonuçlar İ/R modelinin overlerde antioksidan kapasiteyi anlamlı ölçüde azalttığını, I/R öncesinde D vitamini verilmesinin antioksidan kapasite üzerine olumlu etkilerinin olabileceğini göstermektedir (Tablo-1).

Grup 1, Grup 2 ve Grup 3 için over SOD değerleri ise sırasıyla $1.77( \pm 0.03) ; 1.26( \pm 0.11) ; 1.64$ $( \pm 0.07) \mathrm{U} / \mathrm{mL}$ ölçülmüştür. Over dokularında ölçülen SOD enzim aktiviteleri değerlendirildiğinde Grup 2'de ölçülen enzim aktivitesinin Grup1'e göre anlamlı düşük olduğu ( $p=0.004) ; \mathrm{I} / \mathrm{R}$ öncesi D vitamini verilen Grup 3'te ise bu düşmenin anlamlı düzeyde azaldığı görülmüştür $(p=0.033)$. Bu sonuçlar İ/R modelinin over dokusunda önemli bir antioksidan enzim olan SOD aktivitesini anlamlı düzeyde azalttığını, $D$ vitamini verilmesinin ise SOD aktivitesini kısa ve uzun dönemde koruduğunu desteklemektedir (Tablo-1).

Plazma AMH değerleri ise Grup 1'de ortalama olarak $2.09( \pm 0.14) \mathrm{ng} / \mathrm{mL}$ saptanırken, Grup 2'de $1.45( \pm 0.21) \mathrm{ng} / \mathrm{mL}$ ve Grup 3'te 1.67 $( \pm 0.08) \mathrm{ng} / \mathrm{mL}$ saptanmıştır. Plazma AMH sonuçları değerlendirildiğinde Grup 2'de ölçülen $\mathrm{AMH}$ düzeylerinin Grup 1'e göre anlamlı düşük olduğu görülmüştür $(p=0.035)$. Grup 3'te ölçülen $\mathrm{AMH}$ düzeyleri ise Grup 2'ye oranla daha yüksek olmasına karşın iki grup arasında istatistiksel olarak anlamlı fark bulunamamıştır $(p=0.07)$. Bu sonuçlar ışığında çalışmamızda uygulanan I/R modelinin plazma AMH düzeylerinde anlamlı bir azalmaya neden olduğu ve İ/R uygulamasından önce $D$ vitamini verilmesinin over kaynaklı $A M H$ salınımına olumlu etki gösterdiğini desteklemektedir (Tablo-1).

Tablo-1. Plazma ve over dokusunda ölçülen biyokimyasal belirteçler.

\begin{tabular}{lllll}
\hline & Plazma AMH $(\mathrm{ng} / \mathrm{mL})$ & Over MDA $(\mathrm{nM})$ & Over TAK $(\mu \mathrm{M})$ & Over SOD $(\mathrm{U} / \mathrm{mL})$ \\
\hline Grup 1 (Sham) & $2.09 \pm 0.14$ & $152.6 \pm 11.03$ & $210.37 \pm 15.25$ & $1.77 \pm 0.03$ \\
$\begin{array}{l}\text { Grup 2 (i/R) } \\
\begin{array}{l}\text { Grup 3 (D vit+I/R+48 } \\
\text { saat) }\end{array}\end{array}$ & $1.45 \pm 0.21$ & $332.54 \pm 44.51$ & $147.50 \pm 9.48$ & $1.26 \pm 0.11$ \\
\hline
\end{tabular}




\section{TARTIŞMA}

Laparoskopinin açık cerrahiye göre minimal invaziv bir teknik olduğu düşünülmesine rağmen, oluşturulan pneumoperitoneuma bağlı gelişen intraabdominal basınç artışlarının özellikle abdominal organlarda hipoperfüzyona neden olabildiği gerek deneysel gerekse klinik çalışmalarla ortaya konulmuştur. Çalışmamızda $12 \mathrm{mmHg}$ ile oluşturulan pneumoperitonium modelinde overlerde gelişen iskemi-reperfuzyon hasarı tartışılmıştır. Biz diğer çalışmalardan farklı olarak oluşturulan deneysel I/R modelinde $D$ vitamininin oksidatif stresteki koruyucu etkisini biyokimyasal ve histolojik parametreler üzerinden araştırdık. Laparoskopik cerrahinin avantajı hastanede kalış ve rehabilitasyon süresinin kısa olması, güncel aktivitelere erken başlanması, kozmetik iyi sonuçlarının olması, postoperatif komplikasyonlarının ve morbiditenin azlığıdır. Normal intraabdominal basınç $(10-15 \mathrm{~mm} \mathrm{Hg})$ fizyolojik portal sistem basıncından $(7-10 \mathrm{~mm} \mathrm{Hg})$ yüksektir. Bu sebepten intraabdominal basınç artışı abdominal organ ve sistemlerde perfüzyon bozukluğuna neden olmaktadır (1).

Pneumoperitoneum esnasında oluşan $\mathrm{i} / \mathrm{R}$ hasarının solid intraabdominal organlar üzerine olan etkisi biyokimyasal oksidatif stres parametreleri, sitokin düzeyleri ve histopatolojik hasar düzeyi bakılarak çeşitli insan ve hayvan çalışmalarında araştırılmıştır $(2,3)$. Sadece oksidatif stres parametrelerinin incelendiği diğer çalışmalardan farklı olarak, çalışmamızda iskemi reperfüzyon döneminde oluşan oksidatif hasarın doku $\mathrm{AMH}$ düzeyi üzerine olan etkisi de çalışıımış, ayrıca oral D vitamini desteğinin etkinliği araştırımıştır ve nihayetinde gruplar arasında $\mathrm{AMH}$ değerleri arasında anlamlı farklılıklar izlenmiştir.

Doku ve plazmada MDA, SOD, XO (ksantin oksidaz), NO (Nitrik oksit) artışı bu hasarı oluşturmaktadır. Xingwei ve ark. çalışmalarında pneumoperitoneum esnasında 3 . saatte IL-6, TNF, MDA, SOD ve iFABP (intestinal fatty acid binding protein) düzeylerinde artışın multisistem doku hasarına neden olduğunu göstermişlerdir (5). Güven ve ark. Yaptıkları çalışmada pneumoperitoneum esnasında serbest oksijen radikallerinin lipit peroksidasyonu yoluyla oluşturdukları hücresel hasarın ara ürünü olan MDA değerlerinin yükseldiğini göstermişlerdir (3). Çalışmamızdaki oksidatif stres belirteç değerleri önceki çalışmalarla uyumludur.

Nesek-Adam ve ark. pneumoperitoneum esnasında oluşan $\mathrm{I} / \mathrm{R}$ hasarında total antioksidan kapasitenin azaldığını göstermişlerdir (6). Biler ve ark. yapmış oldukları çalışmada da oksidatif stres belirteçleri sonuçları ile benzer sonuçlar alınmıştır (7). Çalışmamızda SOD ve TAK değer dağılımı gruplar arası farlılıklar göstermiş, I/R grubunda antioksidan parametreler TAK ve SOD değerlerinin azaldığı, D vitamini uygulanan grupla kıyaslandığında ise istatistiksel olarak anlamlı düzeyde düşük olduğu izlenmiştir.

Glantzounis ve ark. da laparoskopik cerrahideki pneumoperitoneumun serbest oksijen radikallerini, oksidatif stres belirteçlerini yükselttiğini, bunun ise total antioksidan kapasiteyi azalttığını göstermiştir (8). Bizim çalışmamızda D vitamini desteği yapılmış grupta histolojik skorlamada farklılıklar izlenmiştir.

Kıray ve ark. pneumoperitoneum esnasında over yüzey epitelindeki değişiklikleri elektron mikroskobunda incelemiştir (9). Diğer çalışmalardan farklı olarak over yüzey epitelindeki geri dönüşümlü hasarın $E$ vitamini desteği yapılan grupta daha az olduğunu göstermişlerdir. Sadece intraabdominal basınç artışının bile iskemi, serbest radikal oluşumu, proinflamatuar sitokin artışı sağladığını, apopitos ve diğer yolaklarla (TNF- $\alpha, I L-1, I L-6$ artış।) hücre hasarı oluşturduğunu göstermişlerdir (10).

Yao ve ark. sıçan miyokart dokusunda VDR'nin (vitamin D reseptörü) endojen ve ekzojen aktivasyonunun miyokart enfartüsünde enfarktüs alanını küçülttüğünü miyokart fonksiyonlarını iyileştirdiğini, endoplazmatik retikulumda CCAAT (enhancer-binding protein homologous protein) ve caspas-12 ekspresyon aktivasyonunu sağladığını ve kardiomiyosit apopitosunu azalttığını göstermişlerdir. Bunun dışında VDR aktivasyonunun miyokardiyal iskemik reperfüzyonda otofaji disfonksiyonunu azalttığı ve metallotionin bağımlı oksidatif stres mekanizmalarını inhibe etttiği gösterilmiştir (4).

Ayrıca Goncalves ve ark. çalışmalarında D vitamini eksikliğinin akut böbrek iskemisinden sonra kronik böbrek hastalıklarına progresyonu arttırdığını göstermiştir (11). Ayrıca D vitamininin gastrik epitel hücrelerinde iskemik hasarı önlediği gösterilmiştir (12). Biz de kendi çalışmamızda sıçanlarda oluşturduğumuz laporoskopik pneumoperitoneum modelinde overlerde $\mathrm{I} / \mathrm{R}$ hasarının boyutunu histolojik ve biyokimyasal belirteçlerle araştırdık ve $\mathrm{i} / \mathrm{R}$ hasarının önlenmesinde $D$ vitamini etkinliğinin sonuçlarını değerlendirdik. Elde ettiğimiz veriler ışığında D 
vitamini uygulanan grupta oksidatif hasar boyutunun daha düşük olduğunu gözlemledik.

\section{SONUÇ}

Günlük pratiğimizde görülen overin İ/R hasarının önlenmesi fertilizasyonun korunması açısından önemlidir. D vitamininin etkisi sadece laporoskopik pneumoperitoneum modelinde değil, overin direkt ya da indirekt olarak oksidatif strese maruz kaldığı radyoterapi veya kemoterapi gibi uygulamalar öncesinde de kullanılabilir. D vitamininin insan overindeki etkilerini göstermek için daha geniş çaplı ve kapsamlı araştırmaların gerektiği ise çok açıktır.

\section{Çıkar çatışması}

Hiçbir yazarın herhangi bir firma ile maddi ilişkisi yoktur.

\section{Kaynaklar}

1. Akdemir $\mathrm{A}$, Erbas, $\mathrm{O}$, Ergenoglu $\mathrm{M}$ et al. Montelukast prevents ischemia/reperfusion-induced ovarian damage in rats. Eur J Obstet Gynecol Reprod Biol 2014; 173: 71-6.

2. Ergenoglu M, Erbas $\mathrm{O}$, Akdemir $\mathrm{A}$ et al. Attenuation of ischemia/reperfusion-induced ovarian damage in rats: does edaravone offer protection. Eur Surg Res 2013; 51:21-2.

3. Guven S, Muci E, Unsal MA et al. The effects of carbon dioxide pneumoperitoneum on ovarian blood flow, oxidative stress markers, and morphology during laparoscopy: a rabbit model. Fertil Steril 2010; 93: 1327-32.

4. Yao $T$, Ying $X$, Zhao $Y$, Yuan $A$ et al. Vitamin $D$ receptor activation protects against myocardial reperfusion injury through inhibition of apoptosis and modulation of autophagy. Antioxid Redox Signal. 2015 Mar 10; 22 (8): 633-50.

5. Xingwei $X$, Xin G, Peng $Z$ et al. Low-dose ketamine pretreatment reduces oxidative damage and inflammatory response following CO2 pneumoperitoneum in rats. Clin Invest Med. 2014; 37: E124.

6. Nesek-Adam V, Mrsić V, Smiljanić A et al. Pathophysiologic effects of CO2-pneumoperitoneum in laparoscopic surgery. Acta Med Croatica. 2007 Apr; 61 (2): 165-70.

7. Biler A, Yucebilgin $S$, Sendag $F$ et al. The effects of different intraabdominal pressure protocols in laparoscopic procedures on oxidative stress markers and morphology in rat ovaries. Adv Clin Exp Med. 2014 Nov-Dec; 23 (6): 885-92.

8. Glantzounis GK, Yang W, Koti RS et al. The role of thiols in liver ischemia-reperfusion injury. Curr Pharm Des. 2006; 12 (23): 2891-901.

9. Kiray M, Sisman AR, Camsari UM et al. Effects of carbon dioxide exposure on early brain development in rats. Biotech Histochem. 2014 Jul; 89 (5): 371-83.

10. Yilmaz $\mathrm{S}$, Koken $\mathrm{T}$, Tokyol $\mathrm{C}$ et al. Can preconditioning reduce laparoscopy-induced tissue injury? Surg Endosc 2003; 17: 819-824.

11. Gonçalves JG, de Bragança AC, Canale D. et al. Vitamin D deficiency aggravates chronic kidney disease progression after ischemic acute kidney injury. PLoS One. 2014 Sep 15; 9 (9): e107228.

12. Uberti F, Morsanuto V, Bardelli C, Molinari C. Protective effects of 1a,25-Dihydroxyvitamin D3 on cultured neural cells exposed to catalytic iron. Physiol Rep. 2016 Jun; 4 (11). 